Note

\title{
RESILIENCE OF SOIL MICROBIAL ACTIVITY AND OF AMINO ACID DYNAMICS TO THE REMOVAL OF PLANT CARBON INPUTS DURING WINTER
}

\author{
Elizabeth J. Avramides ${ }^{1}$; Matina Christou ${ }^{1}$; David L. Jones ${ }^{2 *}$ \\ ${ }^{1}$ National Agricultural Research Foundation - NAGREF - Soil Science Institute of Athens - S. Venizelou St - \\ Lycovrissi - Athens 14123 - Greece. \\ ${ }^{2}$ School of the Environment and Natural Resources - Environment Centre Wales - Bangor University - Gwynedd \\ LL57 2UW - Wales - UK. \\ *Corresponding author <d.jones@bangor.ac.uk>
}

\begin{abstract}
Many temperate agricultural soils have prolonged periods in the winter when plant carbon inputs to the soil are low. Soil maintained at low temperature in the absence of plants was used to simulate the conditions in a vineyard soil during winter. In a four month simulated overwintering period we showed that the concentration of dissolved organic carbon and nitrogen in soil solution slowly declined alongside heterotrophic soil respiration. Measurements of free amino acid concentrations and turnover indicated that the amino acid pool in soil was rapidly depleted but readily replenished throughout the four-month period. This indicates that the soil contained intrinsic reserves of labile $\mathrm{C}$ that was capable of supporting the soil microbial community in times of reduced plant $\mathrm{C}$ inputs.
\end{abstract}

Key words: DOC, DON, microbial activity, mineralization, nitrate, storage

\section{RESILIÊNCIA DA ATIVIDADE MICROBIANA E DA DINÂMICA DE AMINO-ÁCIDOS NA REMOÇÃO DAS ADIÇÕES DE CARBONO DAS PLANTAS, DURANTE O INVERNO}

\begin{abstract}
RESUMO: Muitos solos agrícolas de regiões temperadas passam por períodos prolongados de inverno, nos quais a adição de carbono de plantas é muito reduzida. Foi utilizado um solo mantido à baixas temperaturas e na ausência de plantas para simular condições de uma cultura de uva durante o inverno. Em quatro meses de simulação mostrou-se que as concentrações de carbono orgânico e de nitrogênio dissolvidos na solução de solo declinaram lentamente em paralelo à respiração heterotrófica do solo. Medidas de concentração de renovação de amino ácidos livres indicaram que a reserva do solo em aminoácidos foi rapidamente esgotada, mas prontamente reabastecida durante o período de quatro meses. Isto indica que o solo possuía reservas intrínsecas de carbono lábil que foi capaz de sustentar a comunidade microbiana em tempos de adição reduzida de carbono de planta.

Palavras-chave: DOC, DON, atividade microbiana, mineralização, nitrato, armazenamento
\end{abstract}

\section{INTRODUCTION}

Due to pronounced seasonality, the soil microbial community can be expected to have an uneven supply of carbon $(\mathrm{C})$ in both space and time in many temperate environments. For example, $\mathrm{C}$ inputs are known to be higher in the rhizosphere due to root inputs (rhizodeposition) and at the soil surface due to litter and throughfall inputs (Paterson, 2003; Stadler et al., 1998). While inputs into the rhizosphere can change over short time periods and spatial scales (Paterson, 2003; Dilkes et al., 2004; Paterson et al., 2005), large seasonal changes in C inputs are also ap- parent (Fitter et al., 1998; Franzluebbers et al., 1995). It is likely that maximal $\mathrm{C}$ inputs will occur during the most active periods of plant growth or during senescence. In most temperate agricultural environments the inputs of labile $\mathrm{C}$ to the soil can be expected to be lowest during the winter either because no plants are present (e.g. in between annual crops) or because photosynthesis, below-ground $\mathrm{C}$ partitioning or overall plant growth is limited by low temperatures and photoperiod length (Porter \& Delecolle, 1988; Farrar, 1998).

It is here hypothesized that the soil microbial community will undergo severe $\mathrm{C}$ starvation during the 
winter periods due to lack of inputs and that this would be reflected in a progressive temporal decline in the concentration of dissolved organic nutrients in the soil solution. The aim of this study was therefore to investigate the supply of $\mathrm{C}$ to the soil microbial community during these periods of reduced plant input.

\section{MATERIAL AND METHODS}

The soil (sandy clay loam and textured Inceptisol) was collected from an experimental field site located at Lycovrissi, Athens, Greece (38³' N 2339' W). It consisted of a 1 ha vineyard planted in 1983 with Vitis vinifera L. cv. Cabernet Sauvignon. The vineyard contained rows of vines spaced $2 \mathrm{~m}$ apart and managed according to standard Greek vineyard practices. The soil at the site was classified as a sandy clay loam Inceptisol and had the following properties (mean \pm SEM, $n=3$ ): $\mathrm{pH}, 7.52 \pm 0.01$; Electrical conductivity, $276 \pm 34 \mathrm{dS} \mathrm{m}^{-1}$; Total C, $16 \pm 1 \mathrm{~g} \mathrm{~kg}^{-1}$; Total N, 1.4 $\pm 0.1 \mathrm{~g} \mathrm{~kg}^{-1}$; Microbial biomass-C, $401 \pm 53 \mathrm{mg} \mathrm{kg}^{-1}$. Further details of the site and soil are provided in Christou et al. (2006). The mean annual rainfall at the site was $371 \mathrm{~mm}$ and the mean annual soil temperature was $17.4^{\circ} \mathrm{C}\left(\min -4^{\circ} \mathrm{C}, \max 34^{\circ} \mathrm{C}\right)$.

Within a representative area of the vineyard, three independent sampling blocks $2 \times 2 \mathrm{~m}$ in size were selected approximately $10 \mathrm{~m}$ apart. Replicate soil samples were taken from the 0 to $30 \mathrm{~cm}$ layer of each block using a spade and individual samples (ca. 500 $\mathrm{cm}^{3}$ ) stored field-moist at $4^{\circ} \mathrm{C}$ in gas permeable, moisture retentive plastic bags to reflect mean winter temperatures. The moisture content was not actively managed but remained unchanged throughout the experimental period. To minimize physical and biological disturbance, the soils were not sieved or mixed and the soil remained in relatively large aggregates (ca. $1-5 \mathrm{~cm}$ in diameter) throughout the experimental period (Jones $\&$ Willett, 2006). There were few fine roots observable in the soil and no attempt was made to remove the few present as this would have induced physical disturbance. Removal of soil from the field guaranteed no plant inputs and removed the dynamic influence of external climatic factors.

At known times after placement in the refrigerator ( 0 to $140 \mathrm{~d}$ after collection from the field), one independent replicate soil sample from each block was recovered and soil solution extracted by the centrifugal-drainage method of Giesler \& Lundström (1993). Dissolved organic carbon (DOC) and total dissolved nitrogen (TDN) in soil solution were determined with a Shimadzu TOC-TNV analyzer (Shimadzu Corp., Kyoto, Japan). $\mathrm{NH}_{4}^{+}$was determined by the salicylatenitroprusside method of Mulvaney (1996), $\mathrm{NO}_{3}^{-}$deter- mined according to Downes (1978) and free amino acids determined fluorometrically according to Jones et al. (2002). DON was calculated as the difference between the TDN reading and the combined $\mathrm{NH}_{4}^{+}$and $\mathrm{NO}_{3}^{-}$reading (DIN). Total phenols in soil solution were determined using the Folin-Ciocalteau reagent according to Swain \& Hillis (1959) using phenol as a standard. Basal soil respiration was determined on $50 \mathrm{~cm}^{3}$ subsamples of soil in a closed chamber SR1 automated soil respirometer equipped with an infra-red gas analyzer (PP Systems Ltd, Hitchin, UK).

Amino acid mineralization was determined according to Jones et al. (2005). Briefly, a ${ }^{14} \mathrm{C}$-labeled amino acid mixture $\left(20 \mu \mathrm{M} ; 0.35 \mathrm{mg} \mathrm{L}^{-1} \mathrm{~N} ; 0.33 \mathrm{kBq}\right.$ $\mathrm{mL}^{-1}$ ) was added to the soil and the subsequent ${ }^{14} \mathrm{CO}_{2}$ evolution monitored over a $96 \mathrm{~h}$ period. A double first order kinetics model was fitted to the experimental amino acid mineralization data using the equation

${ }^{14} \mathrm{C}-A A_{\text {soil }}=a \times \exp ^{(-b t)}+c \times \exp ^{(-d t)}$

where ${ }^{14} \mathrm{C}-A A_{\text {soil }}$ is the total amount of ${ }^{14} \mathrm{C}$ remaining in the soil and $a, b, c$ and $d$ are first order kinetic constants and $t$ is time $(\mathrm{h})$. The first component of the equation $\left(a \times \exp ^{(-b t)}\right)$ approximates the depletion of amino acids from the soil solution while the second component $\left(c \times \exp ^{(-d t)}\right)$ describes the turnover of amino acid-C immobilized in the soil microbial biomass (Jones et al., 2005). The half-life of amino acid-C in the soil $\left(t_{1 / 2}\right)$ can be calculated from

$t_{1 / 2}=\ln (2) / b$

Equation 1 was fitted to the experimental mineralization data using a least squares optimization routine in Sigmaplot 8.0 (SPSS Inc., Chicago, IL). Statistical analyses (linear regression of temporal trends, paired t-tests comparing two time points, one-way ANOVA with Tukey pair-wise comparison for temporal trends) were performed using Minitab 14 (Minitab Inc., State College, PA).

\section{RESULTS AND DISCUSSION}

The effect of maintaining the soils at $4^{\circ} \mathrm{C}$ (i.e. simulated overwintering) for four months on the chemistry of the soil solution is shown in Figure 1. Overall, the concentration of DOC decreased in soil solution by $39 \pm 3 \%$ from that measured at day 0 $(p<0.05)$, while DON decreased by $37 \pm 9 \%(p<$ $0.05)$. Over the same period, there was a corresponding $34 \pm 11 \%$ increase in $\mathrm{NO}_{3}^{-}$concentration $(p<0.05)$ but almost no change in $\mathrm{NH}_{4}^{+}$concentration $(0.28 \pm$ $0.03 \mathrm{mg} \mathrm{L}^{-1} \mathrm{~N}$; data not presented). No large temporal changes in either soil solution DOC-to-DON ratio or the total concentration of phenolic substances were 
evident ( $p>0.05$; data not presented). The concentration of total free amino acids declined over the simulated overwintering period from $0.22 \pm 0.03 \mathrm{mg}$ $\mathrm{L}^{-1} \mathrm{~N}$ at day zero to $0.09 \pm 0.01 \mathrm{mg} \mathrm{L}^{-1} \mathrm{~N}$ at day 112 $(p<0.05$; Figure 1).

Maintaining the soils at $4^{\circ} \mathrm{C}$ had a major impact on the rate of amino acid turnover and microbial activity. Both basal soil respiration and the rate of amino acid mineralization declined with increasing simulated overwintering time $(p<0.05$; Figure $2)$. The rate of amino acid half-life and basal respiration in the soil were negatively correlated $\left(\mathrm{r}^{2}=0.41\right.$; $p<0.05$ ). The ratio of amino acid-C incorporated into the microbial biomass versus that partitioned into respiration was not, however, largely affected by simulated overwintering time ( $p>0.05$; data not presented).


The soil climatic conditions used here reflect the mean monthly soil temperature from January to February recorded in the field (Christou et al., 2006). In this winter period, the direct inputs of organic $\mathrm{C}$ into the soil from plants can be expected to be extremely low. Our experiments were carried out in the absence of plants and therefore the soil microbial community was dependent upon the intrinsic turnover of soil organic matter and its own biomass to supply labile C. Over a four-month simulated overwintering period, our results showed that the concentration of free amino acids in soil solution declined slowly. Over the same period, we showed that soil microbial activity similarly declined and that amino acid half-life in soil increased. Based upon measurements of amino acid half-life in the field $\left(4.8 \pm 0.7 \mathrm{~h}\right.$ at $5.5^{\circ} \mathrm{C}$; Christou et al., 2006) and measured here $(2.6 \pm 0.1 \mathrm{~h})$ we calcu-
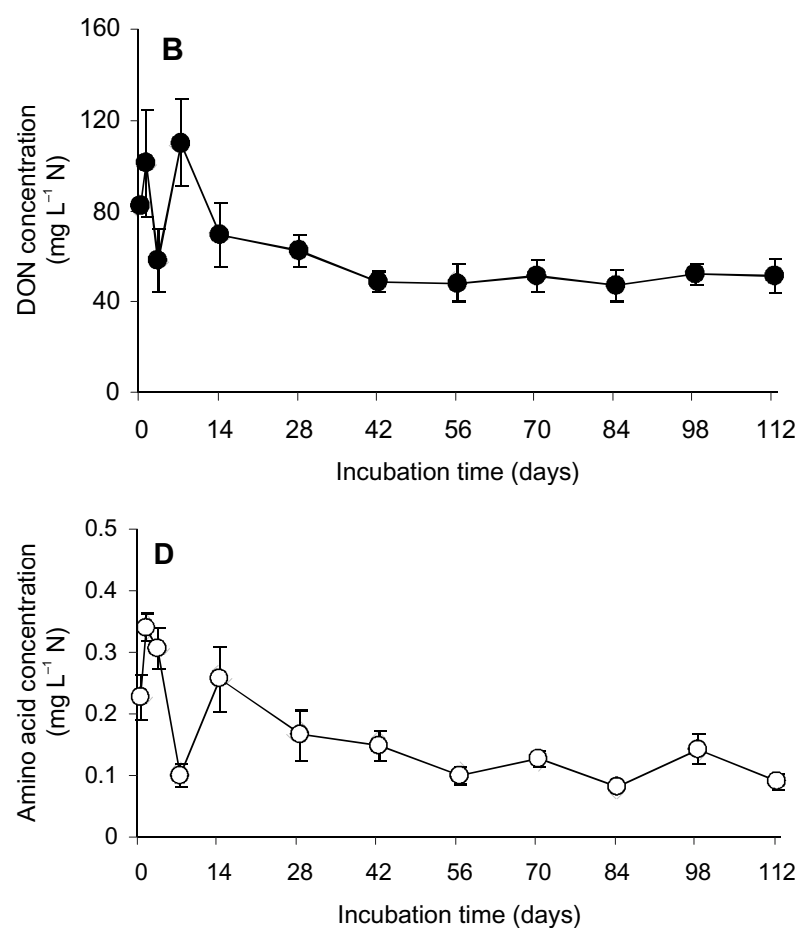

Figure 1 - The effect of soil incubation at $4^{\circ} \mathrm{C}$ on the concentration of (A) dissolved organic carbon (DOC), (B) dissolved organic nitrogen $(D O N),(C)$ nitrate, and (D) total free amino acids in soil solution of a vineyard soil. Values represent means \pm SEM $(n=3)$.

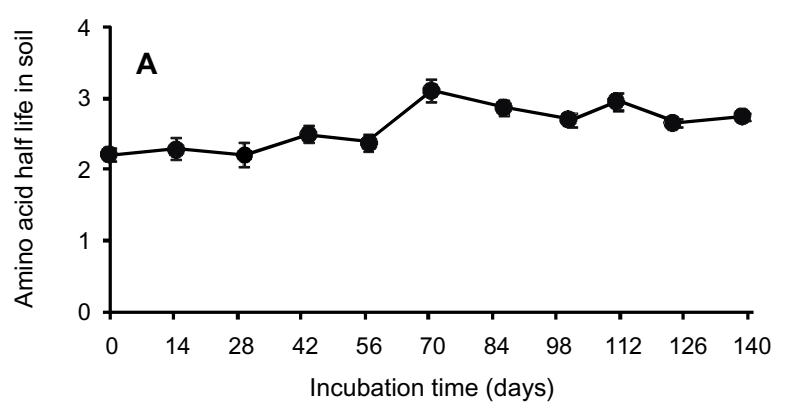

Figure 2 - The effect of soil incubation at $4^{\circ} \mathrm{C}$ on (A) the half-life of free amino acids, and (B) basal soil respiration in a vineyard soil. Values represent means $\pm \operatorname{SEM}(\mathrm{n}=3)$.

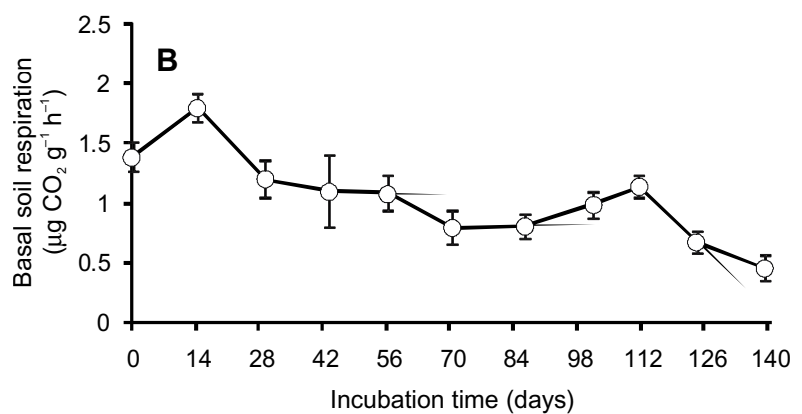

Sci. Agric. (Piracicaba, Braz.), v.66, n.1, p.132-135, January/February 2009 
late that the amino acid pool has turned over approximately 300 times during the four- month storage period and that this is equivalent to $5.7 \%$ of the total basal soil respiration. In this vineyard, senescence occurs around late September and plant growth starts again in late March giving a period of five months of relative plant inactivity due to low soil temperatures and short photoperiod. Our results suggest that there are sufficient reserves of labile $\mathrm{C}$ in the soil to maintain the microbial population in an active state in the absence of significant plant growth. The relative proportion of this labile $\mathrm{C}$ originating from either soil organic matter or from the intrinsic turnover of the biomass itself warrants further studies.

In conclusion, low temperature simulated overwintering of soil caused a gradual decline in the concentration of dissolved organic solutes in soil solution. Even at temperatures reflecting the coldest months for the soil it was apparent that the microbial community was still very active and that lowering the temperature did not inhibit the processing of organic N. This supports previous studies demonstrating significant nitrification in winter in a range of ecosystems (Vance \& David, 1991; Jackson et al., 1994; Gill et al., 1995). Our results also suggest that despite continual microbial activity over a four month period, significant reserves of DOC, DON and amino acids remained in soil. Our results imply that microbial activity will not be unduly affected by a reduced $\mathrm{C}$ supply during the winter periods when the temperature is low and plant inputs are limited.

\section{ACKNOWLEDGEMENTS}

This work was funded by the British Council, the National Agricultural Research Foundation of Greece and the UK Natural Environment Research Council.

\section{REFERENCES}

CHRISTOU, M.; AVRAMIDES, E.J.; JONES, D.L. Dissolved organic nitrogen dynamics in a Mediterranean vineyard soil. Soil Biology \& Biochemistry, v.38, p.2265-2277, 2006.

DILKES, N.B.; JONES, D.L.; FARRAR, J. Temporal dynamics of carbon partitioning and rhizodeposition in wheat. Plant Physiology, v.134, p.706-715, 2004.

DOWNES, M.T. Improved hydrazine reduction method for automated-determination of low nitrate levels in freshwater. Water Research, v.12, p.673-675, 1978.

GIESLER, R.; LUNDSTRÖM, U.S. Soil solution chemistry: the effects of bulking soil samples and spatial variation. Soil Science Society of America Journal, v.57, p.1283-1288, 1993.
FARRAR, J.F. Temperature and the partitioning and translocation of carbon. In: LONG, S.P.; WOODWARD, F.I. (Ed.) Plants and temperature. Cambridge: Society for Experimental Biology, University of Cambridge, 1998. p.203-236.

FITTER, A.H.; GRAVES, J.D.; SELF, G.K.; BROWN, T.K.; BOGIE, D.S.; TAYLOR, K. Root production, turnover and respiration under two grassland types along an altitudinal gradient: influence of temperature and solar radiation. Oecologia, v.114, p.2030, 1998.

FRANZLUEBBERS, A.J.; HONS, F.M.; ZUBERER, D.A. Tillage and crop effects on seasonal soil carbon and nitrogen dynamics. Soil Science Society of America Journal, v.59, p.1618$1624,1995$.

GILL, K.; JARVIS, S.C.; HATCH, D.J. Mineralization of nitrogen in long-term pasture soils - effects of management. Plant and Soil, v.172, p.153-162, 1995.

JACKSON, L.E.; STIVERS, L.J.; WARDEN, B.T.; TANJI, K.K. Crop nitrogen-utilization and soil nitrate loss in a lettuce field. Fertilizer Research, v.37, p.93-105, 1994.

JONES, D.L.; WILLETT, V.B. Experimental evaluation of methods to quantify dissolved organic nitrogen (DON) and dissolved organic carbon (DOC) in soil. Soil Biology \& Biochemistry, v.38, p.991-998, 2006.

JONES, D.L.; OWEN, A.G.; FARRAR, J.F. Simple method to enable the high resolution determination of total free amino acids in soil solutions and soil extracts Soil Biology \& Biochemistry, v.34, p.1893-1902, 2002.

JONES, D.L.; KEMMITT, S.J.; WRIGHT, D.; CUTTLE, S.P.; BOL, R.; EDWARDS, A.C. Rapid intrinsic rates of amino acid biodegradation in soils are unaffected by agricultural management strategy. Soil Biology \& Biochemistry, v.37, p.1267-1275, 2005.

MULVANEY, R.L. Nitrogen: inorganic forms. In: SPARKS, D.L. (Ed.) Methods of soil analysis. Madison: Soil Science Society of America, American Society of Agronomy, 1996. p.11231184.

PATERSON, E. Importance of rhizodeposition in the coupling of plant and microbial productivity. European Journal of Soil Science, v.54, p.741-750, 2003.

PATERSON, E.; THORNTON, B.; MIDWOOD, A.J.; SIM, A Defoliation alters the relative contributions of recent and nonrecent assimilate to root exudation from Festuca rubra. Plant Cell and Environment, v.28, p.1525-1533, 2005.

PORTER, J.R.; DELECOLLE, R. Interaction of temperature with other environmental factors in controlling the development of plants. In: LONG, S.P.; WOODWARD, F.I. (Ed.) Plants and temperature. Cambridge: Society for Experimental Biology, University of Cambridge, 1988. p.133-156.

STADLER, B.; MICHALZIK, B.; MULLER, T. Linking aphid ecology with nutrient fluxes in a coniferous forest. Ecology, v.79, p.1514-1525, 1998.

SWAIN, T.; HILLIS, W.E. The phenolic content of Prunus domestica. Journal of the Science of Food and Agriculture, v. 10, p.63-68, 1959.

VANCE, G.F.; DAVID, M.B. Chemical characteristics and acidity of soluble organic-substances from a northern hardwood forest floor, central Maine, USA. Geochimica et Cosmochimica Acta, v.55, p.3611-3625, 1991.

Received September 11, 2007

Accepted May 26, 2008 